\title{
Modelling of failure rate of water supply network using the Bayes theorem
}

\author{
Dawid Szpak ${ }^{1, *}$, and Barbara Tchórzewska-Cieślak ${ }^{1}$ \\ ${ }^{1}$ Rzeszow University of Technology, Department of Water Supply and Sewage Systems, \\ Al. Powstańców Warszawy 6, 35-959 Rzeszów, Poland
}

\begin{abstract}
The subject of the publication is the analysis and assessment of failure rate of the water supply network in a district city located in southeastern Poland. The analysis was based on the failure rate index. In addition, the paper uses the Bayes theorem to determine the probability of failure of water supply network. The exploitation data obtained from the water supply company were used in the work. It was found that the water supply network of the analysed city is characterized by good technical condition.
\end{abstract}

\section{Introduction}

Access to safe drinking water is undoubtedly one of the basic human rights. The safety of water consumers is understood as the probability of avoiding the risk associated with the consumption of water of a quality incompatible with the current regulation [1], or lack of water supply. Measure of loss of such defined safety is the risk associated with the functioning of collective water supply system (CWSS). Many factors influence the safety of water consumers, including, among others [2-5]:

- the condition of water supply infrastructure,

- the right water treatment technology,

- the condition of the monitoring system,

- exposure to internal and external threats,

- a way to protect consumers from the consequences of undesirable events,

- having specialized repair services,

- having an effective warning system against the threat.

The water distribution subsystem (consisting of water supply network and installations) is the subsystem of CWSS with the highest failure rate. Failure analysis of the water supply network has been the object of interest of scientists for several decades. The important publications of that field are [6,7]. In most publications, failure rate analysis of the water supply network is carried out based on the value of the failure rate index or the availability

\footnotetext{
*Corresponding author: dsz@prz.edu.pl
} 
index. The reliability of the water supply network operation is significantly increased by the implementation of the GIS database [8] and computer hydraulic models [9].

The main purpose of the work is to analyse and assess failure rate of the water supply network of a district town located in south-eastern Poland. The Bayes theorem was used to analyse the probability of failure in the water supply network.

\section{Materials and methods}

The failure rate analysis of the water supply network was performed based on the value of the failure rate index, using the formula $[6,7,10,11]$ :

where:

$$
\lambda=\frac{n(\Delta t)}{L \cdot \Delta t}
$$

$n(\Delta t)$ - the number of failures in the time interval $\Delta \mathrm{t}$,

$L$ - the length of examined pipes in the time interval $\Delta \mathrm{t}[\mathrm{km}]$,

$\Delta t-$ considered period of time [years].

Due to the lack of legal conditions, the obtained results were referred to limit values of the failure rate indices for particular types of pipes, given, among others, in the works [6, 7]:

- the distribution pipes: $\lambda_{D P}=0.50$ failure $/(\mathrm{km} \cdot \mathrm{year})$,

- the household connections: $\lambda_{H C}=1.00$ failure $/(\mathrm{km} \cdot$ year $)$.

The paper uses the Bayes's theorem to determine the probability of failure in the water supply network. The Bayesian theory gives the opportunity to update and correct strong beliefs based on scientific evidence, in the light of new evidence [12-14]:

$$
P(A \mid \mathrm{B})=\frac{P(B \mid \mathrm{A}) \cdot \mathrm{P}(\mathrm{A})}{P(A)}
$$

where:

$\mathrm{P}(\mathrm{A})$ - "a priori" probability of the occurrence of event A, $\mathrm{P}(\mathrm{B})$ - "a priori" probability of the occurrence of event B,

$\mathrm{P}(\mathrm{A} / \mathrm{B})$ - the conditional probability of the occurrence of event $\mathrm{A}$ under condition of the occurrence of event B (it is also called "a posteriori" probability because it comes from, or depends on the value of event $B)$,

$\mathrm{P}(\mathrm{B} / \mathrm{A})$ - the conditional probability of the occurrence of event $\mathrm{B}$, provided the occurrence of event $A$.

\section{Research object}

The analysis was carried out for a district city located in south-eastern Poland. The system of the water supply network is mixed, ring-branched. Unevenness of water consumption is compensated by the end tank with a capacity of $1800 \mathrm{~m}^{3}$. The diagram of the water supply network is shown in Fig. 1. In the analysed water supply network, the distribution pipes and the household connections are distinguished, while there are no classic water supply mains distributing water in the supply area. The system of collective water supply of the analysed city is supplied with water by means of two water intakes [15]:

- $\quad$ bank and wire with efficiency $17280 \mathrm{~m}^{3} / \mathrm{d}$, 
- underground (three drilled wells) with efficiency $348 \mathrm{~m}^{3} / \mathrm{d}$.

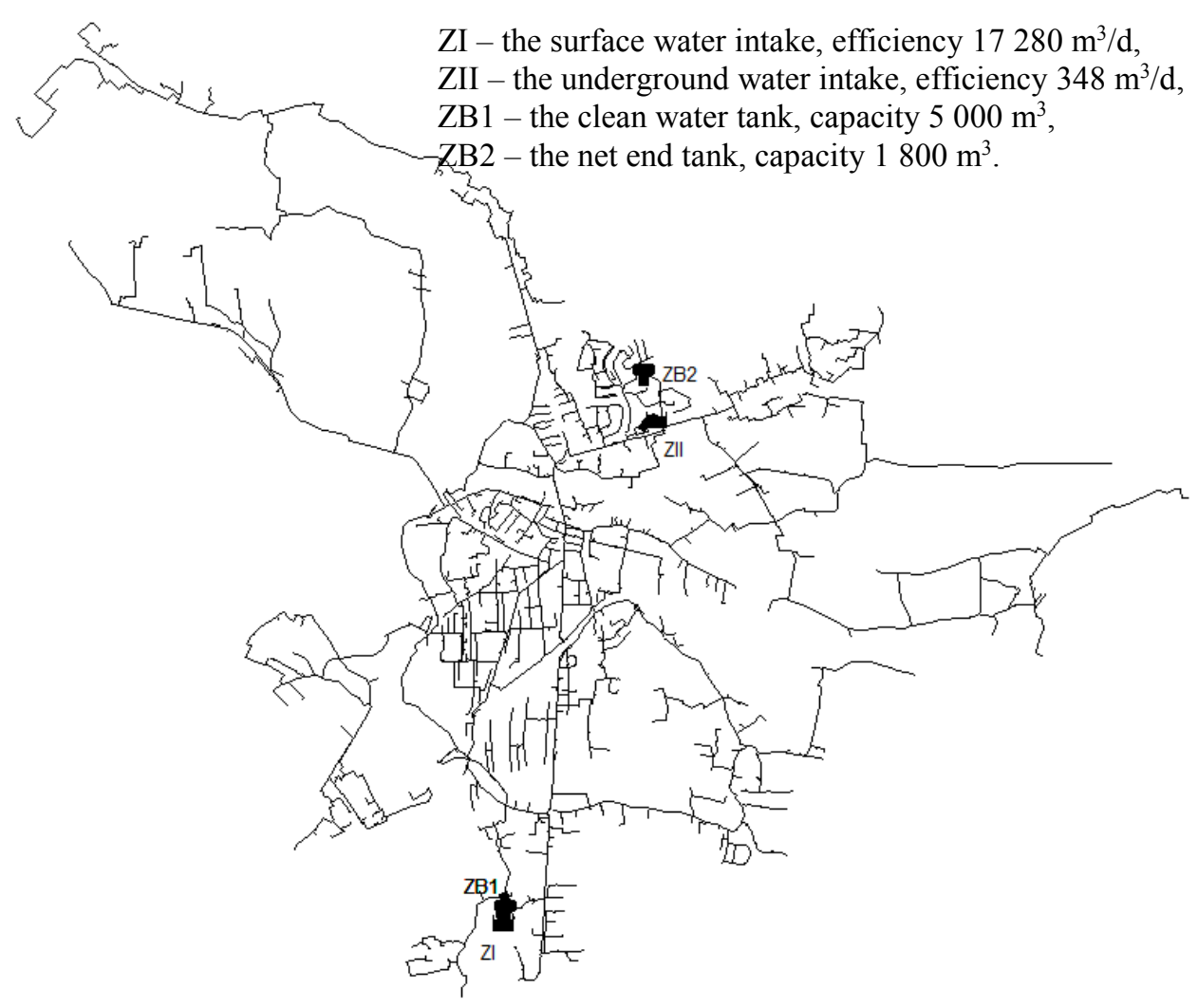

Fig. 1. The diagram of the water supply network.

\section{Results}

The failure rate index determined on the basis of formula (1) is shown in tab. 1. The results of the analysis are also illustrated in Fig. 2. As the received failure rate values are lower than the limit values, it was found that the water supply network of the analysed city is characterized by good technical condition. An increase in the failure rate in the distribution pipes and a decrease in the failure rate in the household connections are noted. The particular attention draws the decrease in the failure rate in the household connections, even though the length of the household connections does not change (the owners of new connections are water consumers, therefore their length is not included by the water supply company, but failures are handled by the company). The actual values of the failure rate in the household connections are therefore lower than those determined on the basis of data provided by the water supply company. 
Table 1. The failure rate index for the distribution pipes and the household connections in 2010-2015.

\begin{tabular}{|c|c|c|c|c|c|c|c|c|c|}
\hline \multirow[b]{2}{*}{ Year } & \multicolumn{3}{|c|}{$\begin{array}{c}\text { The number of } \\
\text { failures }\end{array}$} & \multicolumn{3}{|c|}{$\begin{array}{c}\text { The length of examined } \\
\text { pipes [m] }\end{array}$} & \multicolumn{3}{|c|}{$\begin{array}{c}\text { The failure rate index } \\
\lambda \text { [failure/(km·year)] }\end{array}$} \\
\hline & 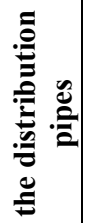 & 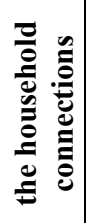 & & 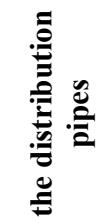 & 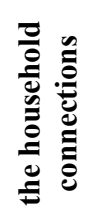 & 产 & 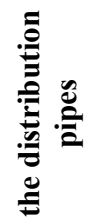 & 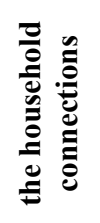 & 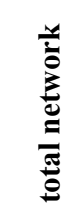 \\
\hline 2010 & 27 & 28 & 55 & 133.9 & 60.0 & 193.9 & 0.20 & 0.47 & 0.28 \\
\hline 2011 & 38 & 18 & 56 & 138.4 & 60.0 & 198.4 & 0.27 & 0.30 & 0.28 \\
\hline 2012 & 38 & 30 & 68 & 140.6 & 60.0 & 200.6 & 0.27 & 0.50 & 0.34 \\
\hline 2013 & 38 & 15 & 53 & 148.6 & 60.0 & 208.6 & 0.25 & 0.25 & 0.25 \\
\hline 2014 & 32 & 14 & 46 & 150.4 & 60.0 & 210.4 & 0.21 & 0.23 & 0.22 \\
\hline 2015 & 61 & 16 & 77 & 152.1 & 60.0 & 212.1 & 0.40 & 0.27 & 0.36 \\
\hline
\end{tabular}

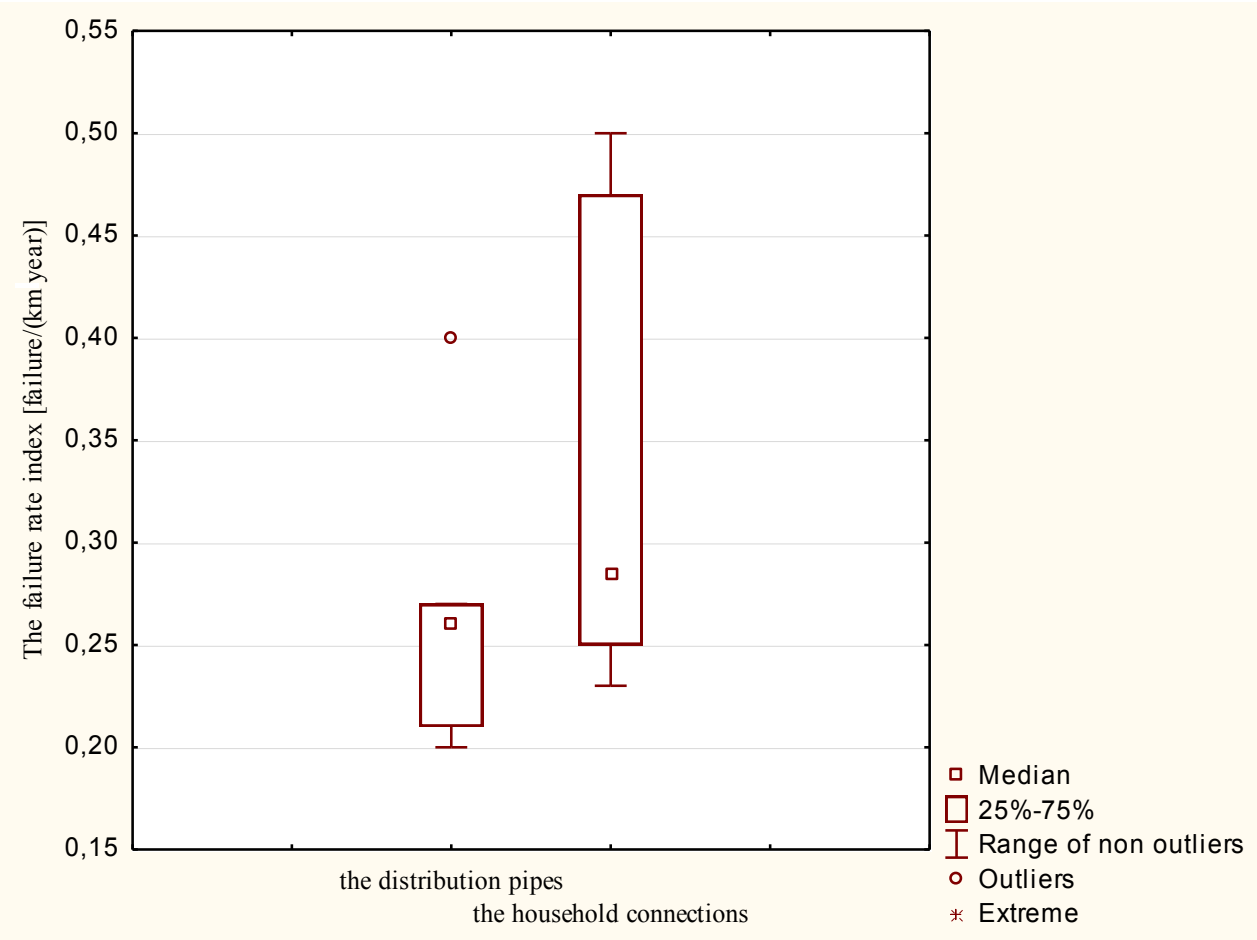

Fig. 2. The failure rate index for the distribution pipes and the household connections in 2010-2015.

Water supply system failures often have result in limitation or lack of water supply to consumers. For this reason, it is important to identify in detail their causes, which allow to identify the actions, which should be taken to increase the reliability of water supply. The 
use of the Bayesian theorem makes it possible to determine the probability of failure in a given type of network [16]. The analysis was carried out for 2015.

According to Table 1, length of the distribution network in 2015 was $152.1 \mathrm{~km}$, while length of the household connections was $60 \mathrm{~km}$. Probability of qualifying the i-th water-pipe to a given type of network:

- the distribution pipes: $\mathrm{P}\left(\mathrm{X}_{1}\right)=\frac{152.1}{212.1}=0.717$,

- the household connections: $\mathrm{P}\left(\mathrm{X}_{2}\right)=\frac{60}{212.1}=0.283$.

According to Table 1, number of failures in the distribution network in 2015 was 61 , while number of failures in the household connections was 16 . The probability of failure in the i-th type of network:

- the distribution pipes: $\mathrm{P}\left(\mathrm{Y} \mid \mathrm{X}_{1}\right)=\frac{61}{77}=0.792$,

- the household connections: $\mathrm{P}\left(\mathrm{Y} \mid \mathrm{X}_{2}\right)=\frac{16}{77}=0.208$.

Total probability that failure will occur:

$\mathrm{P}(\mathrm{Y})=\mathrm{P}\left(\mathrm{X}_{1}\right) \cdot \mathrm{P}\left(\mathrm{Y} \mid \mathrm{X}_{1}\right)+\mathrm{P}\left(\mathrm{X}_{2}\right) \cdot \mathrm{P}\left(\mathrm{Y} \mid \mathrm{X}_{2}\right)=0.717 \cdot 0.792+0.283 \cdot 0.208=0.627$

The conditional probability of failure in the distribution network:

$$
\mathrm{P}\left(\mathrm{X}_{1} \mid \mathrm{Y}\right)=\frac{0.717 \cdot 0.792}{0.717 \cdot 0.792+0.283 \cdot 0.208}=0.906
$$

The conditional probability of failure in the household connections:

$$
\mathrm{P}\left(\mathrm{X}_{2} \mid \mathrm{Y}\right)=\frac{0.283 \cdot 0.208}{0.717 \cdot 0.792+0.283 \cdot 0.208}=0.094
$$

Taking into account the length of the pipes allowed to obtain a new probability value of failure in a given type of pipes. The probability of failure in the distribution pipes is much higher than the probability of failure in the household connections.

\section{Conclusions}

The assessment of failure rate of water supply network should be taken into account decisions which concern the renovation or replacement of water pipes. Water companies have an obligation to ensure continuous and reliable water supply to consumers, where the priority is to ensure the required quality of supplied water.

Based on the values of the failure rate index, it was found that the analysed water supply network is characterized by good technical condition. The average value of the failure rate index for the distribution pipes is $\lambda=0.27$ failure/(km.year) when the limit value is $\lambda_{D P}=0.50$ failure $/(\mathrm{km} \cdot$ year). For the household connections is $\lambda=0.34$ failure $/(\mathrm{km} \cdot$ year) while the limit value is $\lambda_{H \mathrm{C}}=1.00$ failure $/(\mathrm{km} \cdot$ year $)$.

The conditional probability of failure in the distribution pipes is $\mathrm{P}\left(\mathrm{X}_{1} \mid \mathrm{Y}\right)=0.906$ and the conditional probability of failure in the household connections is $P\left(X_{2} \mid Y\right)=0.094$. The method of determining the probability of failure of the water supply network using the Bayes theorem should be applied in the analysis of the safety of network operation.

Further studies in this area should include an attempt to determine the likelihood of a lack of water supply to consumers (a key parameter from the consumers point of view) in relation to a given type of water supply failure. 


\section{References}

1. Rozporządzenie Ministra Zdrowia z dnia 13 listopada 2015 r. w sprawie jakości wody przeznaczonej do spożycia przez ludzi (Dz.U. z 2015 r. poz. 1989)

2. W. Balcerzak, S.M. Rybicki, Journal of Water Supply Research and TechnologyAQUA 60, 7, 459-467 (2011)

3. R. Jafar, I. Shahrour, I. Juran, Mathematical and Computer Modelling 51, (9-10), 1170-1180 (2010).

4. B. Tchórzewska-Cieślak, K. Boryczko, M. Eid, Failure scenarios in water supply system by means of fault tree analysis, In. Advances in Safety, Reliability and Risk Management, A. Grall, Ch. Bérenguer, C. Guedes Soares (Eds.)., Taylor \& Francis Group, 2492-2499, London (2012)

5. B. Tchorzewska-Cieslak, J. Rak, Method of identification of operational states of water supply system, In. Environmental Engineering III - L. Pawlowski, M.R. Dudzinska, A. Pawlowski (Eds.). Taylor \& Francis Group, 521-526, London (2010)

6. H. Hotloś, Ilościowa ocena wplywu wybranych czynników na parametry $i$ koszty eksploatacyjne sieci wodociagowych (Oficyna Wydawnicza Politechniki Wrocławskiej, Wrocław, 2007)

7. M. Kwietniewski, J. Rak, Niezawodność infrastruktury wodociagowej i kanalizacyjnej w Polsce (Komitet Inżynierii Lądowej i Wodnej PAN, Warszawa, 2010)

8. I. Piegdoń, B. Tchórzewska-Cieślak, D. Szpak, The use of geographical information system in the analysis of risk of failure of water supply network, In. Environmental Engineering V - Pawłowska \& Pawłowski (Eds). Taylor \& Francis Group, 7-14, London (2017)

9. K. Pietrucha-Urbanik, A. Studziński, Eksploatacja i niezawodnosc - Maintenance and reliability 19, 3, 317-323 (2017)

10. D. Kowalski, K. Miszta-Kruk, Eng. Fail. Anal. 35, 736-742 (2013)

11. M. Kutyłowska, Period. Polytech-Civ. 66, 1, 1-6 (2017)

12. J.M. Bernardo, A.F.M. Smith, Bayesian theory (Wiley, Chichester, 1993)

13. A. Pagano, R. Giordano, I. Portoghese, U. Fratino, M. Vurro, Natural Hazards 74, 2193-2227 (2014)

14. J. Zhao, J. Jin, Q. Guo, Y. Chen, M. Lu, L. Tinoco, Environ. Sci. Pollut. Res. 21, 3073-3081 (2014)

15. D. Szpak, B. Tchórzewska-Cieślak, Chemik 68, 10, 862-867 (2014)

16. J. Rak, Podstawy bezpieczeństwa systemów zaopatrzenia $w$ wodę (Komitet Inżynierii Srodowiska PAN, Lublin, 2005) 